\title{
Indonesia in the South China Sea: Foreign Policy and Regional Order
}

\author{
I Gede Wahyu Wicaksana \\ Universitas Airlangga
}

\begin{abstract}
This paper looks at how Indonesia contributes to the creation of a relatively peaceful and stable Southeast Asian region after the Cold War. It examines Jakarta's diplomacy in the South China Sea, and explains its implications for the making of the regional order. The argument is that Indonesia's impact on regional security has been apparent in its attention to the improvement of rule-based interaction among states in the region. However, recent developments have demonstrated that Indonesia's initiatives, formulated in the Indo-Pacific Cooperation Concept, are unsuccessful due to the lack of support from other ASEAN states. This paper shows that great powers politics in the troubled waters has hindered the advancement of Indonesian's orderdriven policy.
\end{abstract}

Keywords: ASEAN, Indonesia, Indo-Pacific Concept, Regional Order, South China Sea.

Tulisan ini membahas kontribusi Indonesia dalam menciptakan Kawasan Asia Tenggara yang relatif damai dan stabil setelah Perang Dingin berakhir. Fokus bahasan pada diplomasi yang dilakukan dalam meresolusi konflik Laut China Selatan. Penulis berargumen dampak keterlibatan Indonesia terlihat dari upaya untuk mendorong interaksi yang berdasarkan pada norma dan aturan bersama antar-negara Asia Tetangga. Namun, perkembangan terkini menunjukkan inisiatif Jakarta, khususnya Konsep Kerja Sama Indo-Pasifik, kurang berhasil karena kurang mendapat dukungan anggota ASEAN. Paper ini juga membuktikan bahwa politik kekuatan menjadi hambatan bagi implementasi kebijakan luar negeri Indonesia dalam kasus Laut China Selatan.

Kata-kata kunci: ASEAN, Indonesia, Indo-Pasifik, Laut China Selatan, Tatanan Kawasan. 
How order is formed in the Southeast Asian region and who plays a part in forming the order are interesting questions to address. Specialists on the Southeast Asian region's views differ regarding the process and actors behind the formation of order, depending on their respective theoretical perspectives. According to the dominant perspectives in International Relations theory, such as realism, liberalism and constructivism, there are three contesting views on order. From the realist perspective, order is made through a balance of power, cultivated through military and economic capabilities of the states in the region (Leifer 1999). To liberalists, economic interdependence, multilateral arrangements and global governance create order, in which state and nonstate actors play their roles in promoting functional cooperation (Simon 1996). Beyond the material aspects of realism and liberalism, constructivism views order as being shaped by the socialization of ideas and norms which produces practices and institutions, involving the central role of the state and civil society as reinforcement (Acharya 2000; Haacke 2003). While contradictory, there is a thorough line among the three frames of thought, which is recognition of the role of the state as the agent which constructs order, even so far as regarding states as being politically superior in determining the direction of change in the existing order in the regional and global levels.

Since the focus of this paper is the Southeast Asian region, it may be assumed that the states in the region have a significant part in the establishment of regional order. In addition, the role of external powers such as the United States and China also merits consideration, due to their vast influence in various fields which are used to construct order according to their preference and foreign policies. Thus, order in the Southeast Asian region is consisted of patterns of interaction among regional and extra-regional actors in order to achieve certain goals. Borrowing and combining concepts of order from Bull $(1977,8)$ and Hurrell $(2007,3)$, peace, stability, and intensifying cooperation are the essential goals of the international society. Therefore, in Southeast Asia, the intra- and extra-regional relations are directed to achieve a peaceful, stable and cooperative environment. Nevertheless, according to the realists, order either in peace or wartime is the factual form of order in international politics. Order reflects the status quo that must be accepted. Acharya $(2018,5-7)$ notes that the contestation of ideas regarding order exhibits a situational/descriptive perspective on one hand, and normative on the other, in which constructivism represents the normative order.

In the case of Southeast Asia, this paper's argument is in line with the constructivist way of thinking, in which ideas, norms and institutions comprise the fundamental elements of regional order. Empirical evidence of the establishment and roles of neither the realists' balance of power nor the liberals' economic interdependence in creating a stable and effective regional order has yet to be found. Therefore, a question is asked here as to what kind and whose ideas and norms produce the regional order? A broad answer to this question is of course the ideas and norms originating from the ten member states of the Association of South East Asian Nations (ASEAN). Representation and participation of all ASEAN member states provide the legitimacy to the constructed order. However, for a more specific analytical purpose, this paper will only examine Indonesia's contributions as one of the founding members of ASEAN who has also fulfilled a leadership role in the association, at least in the first three decades since the establishment of ASEAN in 1967. The following part of the paper looks at the ideas and norms Indonesia brings to the plate, in relation to its foreign policy. The paper focuses on Jakarta's role in responding to tension and disputes in the South China Sea 
which is regarded as a demonstration of how internal and external actors interact in the order-making processes in Southeast Asia. The next part of the paper explains the implications of Indonesia's diplomacy for the regional order making. The main points of this paper are reiterated in the conclusion.

\section{Indonesia's Diplomacy in the South China Sea}

The driving issue for Indonesia's involvement in the South China Sea disputes is the overlapping claims over the exclusive economic zone (EEZ) near the waters of the Natuna islands by neighboring countries, including Malaysia, the Philippines, Vietnam, and China. Among the claimants, the issue of Natuna has caused several instances of uneasiness, especially in Indonesia's ties with Vietnam and China. Indonesia claims explorative rights within the 200 nautical mile starting from the outer rims of Natuna, based on rules regarding the rights of archipelagic states as governed by the United Nations Convention on the Law of the Sea (UNCLOS) which was affirmed in December 1982. Vietnam and China are among the signatories of the UNCLOS, but have only formally ratified the law in 1994 and 1996 respectively, whereas Indonesia preceded both by ratifying the law in 1985. Based on UNCLOS, Indonesia's ocean territory formally stretches 12 nautical miles from the baseline of its outermost islands. UNCLOS reinforces the Djuanda Declaration of 1957 which states that the entirety of Indonesia's island territories are linked, and thus the waters between them are part of a united whole. However, the establishment of this jurisdiction was not readily accepted by other maritime states.

Indonesia's diplomatic issue with Vietnam began when Hanoi, at the end of the 1970s, protested Indonesia's efforts to conduct exploration and exploitation of oil and gas sources in the Natuna islands in cooperation with an American company (Khong 1986, 215). However, during the Suharto era, Vietnam's critical position of Indonesia's EEZ in the Natuna never created any serious problems with Indonesia, since the latter was more concerned with the resolution of the conflict in Cambodia, also involving Vietnam. For this reason, Indonesia tended to be more reticent in responding Vietnam's challenge. In addition, foreign policymakers in Jakarta regarded communism in the Indochine as a greater threat to the national and regional security (Suryadinata 1991). In more recent years, interaction has warmed since Indonesia's 'sink the vessels' policy is enacted to foreign vessels, including those of Vietnamese, operating in Indonesian waters and EEZ without permit. Indonesia confiscates and then sinks Vietnamese fishing boats sailing near Natuna. In response, the government in Hanoi accuses the Indonesian navy of violating Vietnam's EEZ for intercepting their fishing boats in the disputed waters (Parameswaran 2015). Such conflicting claims have Jakarta talk with Hanoi. Under the ASEAN principle of dispute settlement, both sides come up with an agreement to work together to fight illegal fishing. Then, President Widodo enhances Indonesia's defense cooperation with Vietnam, particularly in the maritime sector.

In comparison to Vietnam, China is more assertive in claiming territories of the South China Sea. In 1988 the Chinese navy had been involved in a scuffle with Vietnamese warship in the seas next to Spratly islands. This incident brought to Jakarta foreign policy elites' attention that Indonesia must be more proactive in responding to the developments in the South China Sea hotspots. Foreign Minister Ali Alatas facilitated 
workshops on Managing Potential Conflict in the South China Sea. The first event was conducted in Bali, January 1990 and as a first step only involved ASEAN member states. In the second workshop, hosted in Bandung, July 1991, China, Laos, Taiwan and Vietnam took part along with the six ASEAN member states. As the host, Indonesia avoided discussions regarding the precarious subject of territorial sovereignty in the South China Sea, and directed focus on efforts to finding a common ground for multilaterally acceptable solutions to the disputes (Usman and Sukma 1997, 11; 14-18). In his welcome speech in the workshop in Bandung, Alatas $(1991,2)$ expressed that the goal of the meeting is to find a joint solution in order to diffuse tension and transform potential conflict into mutual benefit.

However, Indonesia had not anticipated China's response. In the Surabaya workshop in 1993, China exhibited a historic map of the waters traditionally belonging to its territory. The Indonesian government found that China's nine-dash line overlapped with Indonesia's EEZ in the northern Natuna seas. Therefore, Alatas requested a clarification for the legal basis of the nine-dash line. China ignored Indonesia's request. Once more, Alatas sent a diplomatic note to Beijing requesting a formal statement. Although Jakarta pursued diplomatic means, the Indonesian Foreign Ministry had never made any public statements about the Natuna issue, in order not to give off the impression of legitimizing China's territorial claim (Arsana and Schofield 2012, 68). In June 1995, The Ministry of Foreign Affairs of the People's Republic of China offered a bilateral negotiation to discuss problems regarding borders in the Natuna waters. Beijing's offer was made less than a year before the ratification of UNCLOS by the Chinese government. UNCLOS regulates that issues on sea boundaries among archipelagic states must be discussed bilaterally between the disputing countries. This suggests that China was seeking to advance bilateralism and hinder Indonesia's multilateral dispute settlement efforts. In response to Beijing, Jakarta considered that a negotiation about shared borders was unnecessary, because the fact is Indonesia and China do not have a direct sea boundary around Natuna. The region China claimed with the nine-dash line had not been in accordance to UNCLOS regulation, and as such was of no importance to Indonesia. During his visit to Beijing in 1999, Alatas again mentioned his request to China for a clarification, but the response he received was unsatisfactory (Weatherbee 2016, 4). Another initiative from Indonesia in managing the situation in the South China Sea was a proposal for all disputing countries, including ASEAN member states and China, to declare their 200 nautical mile EEZ per UNCLOS regulation. The remaining territory beyond the EEZ at the center of the seas is left to be exploited through a collective agreement (Johnson 1997, 157). This proposal was rejected by Beijing.

Turbulence caused by the East Asian Financial Crisis and the democratization process in Indonesia diverted Jakarta's attention from the Natuna issue. The geopolitical dynamics in the Asia Pacific region also forced Beijing to adjust its approach to Southeast Asia. As tension subsided, Beijing's concern was directed to the more pressing economically-related issues which had been on the rise since the early 1990 . Bilateral discussions between ASEAN and China eventually bore fruit. In 2002, ASEAN and China agreed on a Declaration on the Conduct of Parties in the South China Sea. Despite the non-binding nature of the agreement, all parties involved committed to adhere to norms such as non-use of force and respect for state sovereignty in their interaction in the South China Sea. China, the Philippines and Vietnam also approved a trilateral exploitation zone in the disputed area (Schofield and Storey 2009, 19). 
Jakarta had also taken advantage of this momentum of tension reduction to bind Beijing into a stronger and more comprehensive bilateral cooperation framework. A scheme for the strategic partnership agreement between the two parties was affirmed in 2005. Through political and economic diplomacy, the Indonesian government sought to promote a foreign policy agenda of rule-based relations between Indonesia, ASEAN and China. President Yudhoyono often mentions the policy doctrine 'Indonesian foreign policy is a million friend zero enemy'. Order-driven policy was a dominant feature of his foreign policy.

Another diplomatic dispute occurred with the transition of leadership, dynamics in domestic politics, and China's increasing demand for energy. In May 2010, the government of China sent a note to the United Nations Secretary General stating that China has legitimate territorial sovereignty as well as sovereign rights on the islands in the South China Sea and the surrounding waters (Weatherbee 2016, 5). China's assertion shows to Jakarta that a stronger claim than before is yet to come. Speculation arose in Jakarta that China would expand the reach of its territorial claim beyond the nine-dash line. Nationalists in Jakarta appeared to respond defensively. Furthermore, in 2008, 2009 and 2010 saw confrontations in the Natuna region, when the Chinese navy prevented Indonesian patrol ships from capturing Chinese fishing boats and fishermen operating within Indonesia's EEZ (Roza 2013, 48-55). The Indonesian government responded to China's note by sending a reply note to the United Nations Secretary General asserting the rejection of China's territorial claim. The Indonesian Foreign Ministry also stated that China's claim of the territory within the nine-dash line had no legal basis, as regulated in the UNCLOS (Weatherbee 2016, 5).

While the contradiction between Indonesia's and China's position regarding sovereign rights and the sporadic incidents involving marine security guards of the two states have never escalated into a full bilateral conflict, Jakarta recognizes that its interaction with Beijing in the Natuna and the South China Sea may become an entryway for foreign intervention in ASEAN and compromises the stability of the Southeast Asian region. In June 2012, for the first time in ASEAN history, a meeting of ASEAN foreign ministers, taking place in Phnom Penh, failed to produce a joint communique due to dissenting views on the South China Sea dispute. Indonesia was quick to prevent discord caused also by negative developments outside of the meeting. Foreign Minister Marty Natalegawa conducted a marathon of diplomatic visits Cambodia, the Philippines and Vietnam which resulted in an agreement which consisted of six central principles, as Natalegawa declared. Based on the result of Indonesia's diplomatic efforts, Cambodia released an ASEAN Statement which contains a call for self-restraint and non-use of force, speeding up the adoption of the code of conduct in the South China Sea, and conflict resolution based on international law, particularly on the regulations in UNCLOS. Indonesia also distributed the zero draft on the Code of Conduct in the South China Sea to the ASEAN colleagues during the break on the $37^{\text {th }}$ regular session in the United Nations General Assembly, September 2012. Indonesia proposed a three plus one formula during the ASEAN Foreign Ministerial Meeting and ASEAN-China Foreign Ministerial Meeting in August 2013. The three plus one formula provides a crisis management framework, in which the first three refers to trust and confidence building, incidents prevention, and incidents management when they occur. The plus one is aimed at preparing for conducive situation to peacebuilding. This includes securing communication hotlines and search and rescue procedures (Roberts and Widyaningsih 2015, 268-9). At this stage, Indonesia could claim able to maintain 
ASEAN cohesiveness, although the ideas put forward had not yet come into reality.

Developments following 2012 demonstrates an increasingly complicated situation. Incident after incident continue to occur in the South China Sea, in the form of both unilateral Chinese actions and clashes with other claimant states. Another highlight is the increasing involvement of the United States in the South China Sea in order to rival China. Indonesia sustains its effort to carry out diplomacy in order to mitigate the impact of the increasingly intensive show of force. The Workshop on Managing Potential Conflict in the South China Sea continues to be held, with the goal of encouraging approval for the Code of Conduct that will bind all parties in the disputes into a peaceful mechanism of conflict resolution. However, Jakarta's efforts did not result in any significant progress. In fact, ASEAN member states' differing positions on the issue are increasingly apparent in addressing China's behavior. In April 2016, China with Brunei, Cambodia and Laos agreed to eliminate the South China Sea issue from the agenda of regular ASEAN-China meetings. Two months later, ASEAN withdrew a statement of concern about China's assertiveness in the disputed region. Perhaps, because of Beijing's pressure on ASEAN. In fact, ASEAN is indeed no longer autonomous and solid in regards to the South China Sea issue (Emmers and Teo 2018, 42). Responding to this complexity, President Widodo's government only continues the diplomatic approach of the previous government. Although in some cases, such as in guarding the Natuna territory, the Indonesian government appears to be more proactive, but the method used to approach to the developing situation is still oriented to the maintenance of rule-based interactions (McRae 2019).

\section{Implications for Regional Order}

Indonesia's failure to put forward its initiative to resolve the South China Sea disputes and the internal dynamics within ASEAN since 2012 raise the questions of which direction is the order-making process in Southeast Asia heading? Will ASEAN be able to maintain its centrality amid the increasing rivalries between Washington and Beijing, or would ASEAN at least be able to maintain its autonomy in responding to geostrategic developments in the region? How can Indonesia contribute to maintaining order in Southeast Asia? These questions require responses in the form of a more thorough investigation into the internal problems experienced by order-makers in Southeast Asia. The link between internal environment and developments unfolding around the region is an analytical instrument that can be used. Within the context of Indonesia as an order-builder, understanding changes in the structure of foreign policy and how those changes produce an idea of Indonesia's role in the region can give an explanation.

Intra-ASEAN politics reveals a sense of mistrust among member states, as by product of the geopolitical conflict during the decolonization period, and continually hinders the effectiveness of interstate conflict management. Sensitivity towards external intervention is the reason behind the rejection from several key member states to Indonesia's proposal for ASEAN to build a regional peacekeeping force. Therefore, the ASEAN Political and Security Community's function tends to be directed to conflict prevention or avoidance, whereas the mechanism for conflict management and resolution stay undeveloped (Emmers 2017). The enduring mistrust may also serve as 
a risk factor for the increasing disunity in ASEAN, while great economic and military powers the likes of the United States and China continue to extend their spheres of influence in Southeast Asia. For example, mega-regionalism through the Regional Comprehensive Economic Partnership (RCEP) trade deal and the Trans-Pacific Partnership (TPP), respectively driven by Beijing and Washington further complicate the economic and strategic geopolitical constellation of power that divides ASEAN member states' position.

Jakarta's diplomatic efforts in establishing ASEAN centrality as well as in encouraging the great powers' engagement within the regional security structures governed by rulebased approach, such as in the ASEAN Regional Forum (ARF), ASEAN Plus Three (APT), East Asia Summit (EAS), ASEAN Defense Ministers' Meeting (ADMM) and ADMM Plus, have proven to be quite effective in promoting the agenda of normative security multilateralism in the wider Asia Pacific region by including all main actors. However, while those institutions are capable of facilitating security dialogue and cooperation among the claimant states in the South China Sea disputes, how the ASEAN version of multilateralism may put pressure on the rivalled great powers to reduce their competition and tension, or at least how Indonesia and ASEAN can make the United States and China not force the Southeast Asian states to choose a side between the two great powers, are questions that need to be answered. Is this security strategy based on normative agendas sufficient in maintaining order? From Indonesian perspective, this approach may be the only viable one available for the country. Moreover, the leadership role to which Jakarta has aspired, is always hindered by domestic weaknesses or the limitation of resources. Hence, the diplomatic concepts being proposed often not backed by the real domestic conditions. This may also explain why, although Indonesia is accepted as the natural leader of ASEAN, its leadership role is in some occasions ignored by the other members of the association (Liow 2018). Developments in the last five years have illustrated the difficulty on Jakarta's part in fashioning Indonesia's proposal regarding regional order building to be accepted by ASEAN partners.

For the foreign policy elites in Jakarta, the most important lesson from ASEAN's failure in determining a singular attitude towards the South China Sea issues, is the requirement to create innovation in order to maintain ASEAN centrality and regional order which, for more than four decades, have contributed a great deal to the region's stability and Indonesia's economic development. The idea underlying the order making concept in this case is how to actualize geographical potential into political influence capable to discipline states in the region, more importantly external actors with conflicting interests in the South China Sea. In May 2013, Foreign Minister Natalegawa published his idea for an Indo-Pacific Treaty of Friendship and Cooperation. His reference regarding the Indo-Pacific is to Indonesia's geographical position between two oceans, the Indian Ocean and Pacific Ocean. According to the Indonesian foreign minister, the identity of the two regions has long been separated, and that the time has come to integrate them into one geoeconomic, political, and strategic identity. Behind this integration is a common interest that must be accommodated, which is the security of the most strategic maritime routes from the Pacific Ocean to the Indian Ocean. Through an understanding of security as a common interest, Natalegawa invited the regional states to build an order based on norms and principles in the ASEAN TAC of 1976. In addition, he also referred to universal norms, such as in the United Nations Charter, the Bandung Declaration of 1955, and the Bali Principles of 2011 which was 
approved by the leaders of the EAS (Natalegawa 2013). There are no new normative attributes added to the TAC proposal for Indo-Pacific. Perhaps, Natalegawa wants to reinvigorate the value of ASEAN-led order and transplant it into a newly defined political realm, considered to be able to provide Indonesia with a fresh opportunity for playing a larger international role. This was consistent with Yudhoyono's globalist internationalism approach to Indonesia's foreign policy, which had given the country the status as a rising middle power.

However, the Southeast Asian responses toward Indonesia's proposal has shown a lack of enthusiasm. The idea of Indo-Pacific Treaty of Friendship and Cooperation was welcome by ASEAN colleagues, and was included into the regional security agenda at the yearly meetings of ASEAN foreign ministers and heads of states in 2013 and 2014. However, no concrete actions were taken to actually establish it (Natalegawa 2018, 104-7). When Brunei became the ASEAN chair in 2013, another proposal from Indonesia regarding social and economic development in Southeast Asia also did not get a great deal of attention (Roberts \& Widyaningsih 2015, 273). The cause may be that other ASEAN member states did not see the urgency for a treaty in as large a region as the Indo-Pacific, even with Indonesia's efforts in convincing other member states of the potential for the negative impacts the tension and contestation among great powers in the South China sea can have on the Indian Ocean. In addition, for the ASEAN member states with already differing positions in regards of the great powers' dynamic, situational considerations about the future of the regional order is more viable than the normative agenda promoted by Indonesia. There had been a clear gap in perception and policy among ASEAN member states that Jakarta was unable to bridge.

The Widodo government since October 2014 has displayed a different foreign policy orientation to the position and agenda of President Yudhoyono. In Widodo's era, a globalist internationalism approach based on ASEAN was abandoned for a nationalist but expansive strategic regional vision. In the campaign document titled Visi Misi Jokowi-Jusuf Kalla (2014) it is stated that Indonesia must be at the center of all maritime activities in the Indian Ocean and Pacific Ocean. The natural geostrategic advantage of Indonesia's location at the intersection of the two oceans is further developed into a geoeconomic and geopolitical power as the Global Maritime Fulcrum. Therefore, Indonesia's role is strengthened in the field of maritime security, including in the safeguarding of marine resources, national territory and handling of transnational crime in the national and regional maritime areas. According to Widodo, the future of Indonesia's economy lies in the seas ("Bagi Jokowi Bukan Sekadar Simbolisme" 2014). The working plan for the Global Maritime Fulcrum is devised systematically and in more detail in policy document known as Kebijakan Maritim Nasional (2017). ASEAN's role seems to be marginalized, both in the programs of the Visi Misi JokowiJusuf Kalla and Kebijakan Maritim Nasional, there is no clear description of how ASEAN is meant to Indonesia's endeavor of becoming the cross-regional maritime power. The first annual address made by Widodo's Foreign Minister, Retno Marsudi, in early January 2013 also did not mention ASEAN's significance to the state's maritime vision.

Widodo first introduced Indonesia's strategic vision as the Global Maritime Fulcrum at the EAS meeting, November 2014. Subsequently, in March 2015 in a visit to Beijing, Widodo expressed the desire to combine Indonesia's Global Maritime Fulcrum with 
China's Belt and Road Initiative. The goal is to attract Chinese investors to fund the infrastructure development for the maritime state. China's Belt and Road Initiative was declared for the first time in President Xi Jinping's speech before the Indonesian Parliament, October 2013. However, the Yudhoyono government did not deem Xi's signal as requiring a swift response. On the contrary, the Widodo government considers the significance of China's Belt and Road Initiative to Jakarta's regional political projection. Thus, speculations arise that Indonesia is moving closer to China. This is strongly indicated by the fact that between 2015 and 2016 Widodo was absent from the Asia Pacific Economic Cooperation (APEC) summits. APEC was established in the early 1990 s with the strong endorsement from Washington. Widodo was only present at the APEC meeting hosted by China (Weatherbee 2017). Another discernable change is the absence of the proposal for the Indo-Pacific Treaty of Friendship and Cooperation from the agenda of ASEAN meetings between 2015 to 2017. There was also a lack of swift response from Jakarta to internal ASEAN turmoil regarding the South China Sea issue in 2016. For Widodo, Indonesia does not need to rely on ASEAN as the main vehicle for the country's foreign policy. Jakarta's role must be broadened beyond ASEAN's conservatism. An alternative would be a more active role in the Indian Ocean through the Indian Ocean Rim Organization, of which Indonesia was the chair for the 2015-2017 period.

Nonetheless, with a critical observation, the first three years of Widodo's presidency never saw any serious efforts in achieving the ideal of Global Maritime Fulcrum. Indonesia became even more protectionist in its international trade sector. With the rhetoric of economic nationalism, various pro-local economy policies were developed. State-owned enterprises monopolize strategic domestic infrastructure development projects. Domestic actors were discouraged from developing their business abroad and were facilitated to dominate the domestic market (Robison and Hadiz 2017). The group of elite nationalists blames foreigners as the perpetrators of all domestic problems (Aspinall 2016). The various external problems expressed by politicians in Jakarta indicate skepticism directed at the liberal order that brought with it democracy, human rights, free trade and multilateral security arrangement. The agenda that is highlighted in the foreign policy portrays pro-populist political orientation in the discourse of people-oriented foreign policy, which is in consonant with the dominant ideology in domestic politics, religious nationalism (Wicaksana n.d.).

The end of 2017 proved to be an important moment for Jakarta to review Indonesia's foreign policy, especially in relation to intra-ASEAN relations and ASEAN's relations with the Indo-Pacific. At an APEC summit, November 2017 in Da Nang Vietnam, President of the United States, Donald Trump gave a suggestion for a Free and Open Indo-Pacific. The central idea being that of the strengthening of the security regionalism in contending with China's aggressiveness, seen to be directly attacking the American world order ("Remarks by President Trump," 2017). The concept of Free and Open IndoPacific then serves as the basis for the revitalization of the security dialogue between the United States, Australia, India and Japan -known as Quad- which had been initiated in the previous decade ("India to Hold Quad," 2018). In the context of the South China Sea disputes, Washington asserts that the Free and Open Indo-Pacific policy includes the enforcement of the rule of law and freedom of navigation, two international norms with which Beijing do not comply. To show its commitment to the implementation of a Free and Open Indo-Pacific, the Pacific Command Center in Honolulu was expanded to the Indo-Pacific Command (Martinez 2018), which includes not only the conflict 
zone in the South China Sea, but the Indian Ocean as well. Washington's political and military gesture is clearly directed at China's expansion in the Northwest Asia and the Indian Ocean through the development of maritime infrastructure which supports the Silk Road route. The situation that subsequently transpires displays the more open great power contestation. Beijing is of the conviction that Trump is executing a containment policy towards China (Jiangtae and Zhou 2017), an indication that may be interpreted as the revival of Asian Cold War.

In Jakarta, these developments are the object of serious concern. The nationalist military generals and politicians, including the government's inner circle, have started to speak out about the security risk that Indonesia must face if a crisis were to happen between Beijing and Washington. The Ministry of Foreign Affairs also reconsidered the concept for a middle way policy in order to avoid having to choose Beijing or Washington. Similar concern came about in other ASEAN member states' capitals. The governments' concern is focused on the issue of the decline of ASEAN centrality amid great power politics of rivalries seem to be difficult to cover up.

As an enforcer of regional order, Foreign Minister Marsudi initiates the concept about Indo-Pacific cooperation (Tham 2018). In contrast to motivations behind the IndoPacific Treaty of Friendship and Cooperation brought to ASEAN by Foreign Minister Natalegawa, Marsudi took off from the reasoning that treaties are a complicating format, in addition to the legal bind which put off ASEAN members and Indo-Pacific partners, the mechanism for ratifying a treaty also requires time before it can be enacted. Therefore, Marsudi suggests the Indo-Pacific concept which relies on the principles of interaction such as openness, transparency, inclusiveness, mutual cooperation, international camaraderie, and international law enforcement. Marsudi considers three main areas to act as starting points for the Indo-Pacific cooperation, which include maritime security, maritime connectivity and sustainable development. In the political area, Marsudi asserts the strategy of mutual political and economic gain to preclude the effect of alternative scenarios to both Beijing and Washington. For this reason, the Indonesian foreign minister emphasizes that ASEAN must maintain their solidarity, and that this solidarity will provide the ground on which centrality can be maintained. With ASEAN centrality, the United States and China will not be able to control the Indo-Pacific cooperation. Beginning in August 2018, Marsudi has been approaching ASEAN colleagues to get them to accept the Indo-Pacific concept (Augesti 2018).

In fact, similar to Natalegawa's experience, Marsudi's efforts to further Indonesia's concept in the regional forum met with some degree of difficulty. Although the ideas put forward are substantiated as well as closely related to ASEAN's collective interests, this does not have a positive correlation to Indonesia's agency for ordering the region. Various factors may be at play, two of which are readily apparent: first, ASEAN member states' reluctance to accept the Indo-Pacific concept as the extension of Indonesia's interest to become a maritime power in the Indian Ocean and Pacific Ocean; and second, strategies enacted by Beijing and Washington to rally individual support from ASEAN members for their respective orders has succeeded in convincing ASEAN states' foreign policymakers that an alternative order is no longer necessary. If this second factor is indeed impactful, it shows that Indonesia's order-making agenda, which is based on normative security approach, will face greater challenges in the future. 


\section{Conclusion}

Returning to the initial question of how order is constructed in Southeast Asia, this paper concludes that Indonesia has made an effort to contribute through the promotion of a normative agenda within the ASEAN organization. But it is not always easy for Jakarta to rally support for the ideas and norms it proposes. In spite of the frequent ignorance of Indonesia's leadership from other ASEAN members, many of Indonesia's achievements may still be seen. Through ASEAN, Indonesia develops practices and institutions which place the association at the center of order-making in the region.

In contending with great power rivalries, especially the United States and China in the South China Sea, Jakarta has put forward various initiatives to resolve the disputes between claimant states, in order to prevent regional disputes from becoming arenas for contestation between Washington and Beijing which bears the risk of being destructive towards order in Southeast Asia. However, Jakarta's proposal has not yet produced any significant results. On the contrary, the influence of the rivaled great powers has become more and more apparent in ASEAN. The cohesion and centrality of ASEAN also faces great challenges from the dynamic situation. What is at stake for Jakarta is the stability and harmony in Southeast Asia it has enjoyed for over four decades, and the contribution regional order has to the country's economic development. Therefore, Jakarta continues to look for a formula for solution of the ASEAN's common security problem. What has been recently done by Jakarta is raising the Indo-Pacific concept to the ASEAN forum as an alternative choice between the United States or China. However, this initiative has also yet to be responded to as an urgent matter by ASEAN. Thus, from the Indonesian perspective, the construction of order in Southeast Asia in the future remains a question to be answered.

\section{References}

\section{Book and Book Chapter}

Acharya, A., 2000. Constructing a security community in Southeast Asia: ASEAN and the problem of regional order. Routledge.

Acharya, A., 2018. Constructing Global Order: agency and change in world politics. Cambridge University Press.

Arsana, I. M., and C. Schofield, 2012. "Indonesia's 'invisible' border with China". In Elleman, B., Kotkin, S. and Schofield, C., 2015. Beijing's power and China's borders: Twenty neighbors in Asia, 61-80. Abingdon: Routledge.

Bull, H., 2002. The anarchical society: a study of order in world politics. $3^{\text {rd }}$ edition. Basingstoke: Macmillan International Higher Education.

Emmers, R. and S. Teo, 2018. Security Strategies of Middle Powers in the Asia Pacific. Melbourne University Publishing.

Hurrell, A., 2007. On global order: Power, values, and the constitution of international society. Oxford: Oxford University Press. 
Khong, C. O., 1986. The politics of oil in Indonesia: Foreign company-host government relations. New York: Cambridge University Press.

Natalegawa, M., 2018. Does ASEAN matter? A view from within. Singapore: ISEASYusof Ishak Institute.

Roberts, C. B., and E. Widyaningsih, 2015. "Indonesian leadership in ASEAN: Mediation, Agency and Extra-Regional Diplomacy". In Roberts, C., Habir, A. and Sebastian, L. eds., 2015. Indonesia's ascent: Power, leadership, and the regional order, 264-266. New York: Palgrave Macmillan.

Roza, R., et al., 2013. Konflik Laut China Selatan dan implikasinya terhadap kawasan. Jakarta: P3DI Setjen DPR Republik Indonesia dan Azza Grafika.

Schofield, C. and I. Storey, 2009. The South China Sea dispute: Increasing stakes and rising tensions. Washington, DC: The Jamestown Foundation.

Simon, S., 1996. "The Parallel Tracks of Asian Multilateralism”. In R. Ellings and S. Simon (Eds)., 1996. Southeast Asian Security in the New Millennium, 13-34. Armonk, NY: M.E. Sharpe.

Usman, A., and R. Sukma, 1997. Konflik Laut China Selatan: Tantangan bagi ASEAN (The South China Sea Conflict: Challenges to ASEAN). Jakarta: CSIS.

\section{Journal and Online Journal}

Haacke, J., 2003. "ASEAN's diplomatic and security culture: a constructivist assessment", International relations of the Asia-Pacific, 3(1): 57-87.

Johnson, D., 1997. “Drawn into the fray: Indonesia's Natuna Islands meet China's long gaze South”, Asian Affairs: An American Review, 24(3):153-161.

Leifer, M., 1999. “The ASEAN peace process: A 'category mistake”, The Pacific Review 12(1): 25-39.

McRae, D., 2019. "Indonesia's South China Sea diplomacy: A foreign policy illiberal turn?”, Journal of Contemporary Asia:1-21

Robison, R. and Hadiz, V.R., 2017. "Indonesia: a tale of misplaced expectations", The Pacific Review, 30(6): 895-909.

Suryadinata, L. 1991. "Indonesia-Vietnam relations under Soeharto", Contemporary Southeast Asia. 12(4): 331-346.

Weatherbee, D. E., 2005. "Indonesian foreign policy: A wounded phoenix", Southeast Asian Affairs, 2005(1): 150-170.

Weatherbee, D. E., 2016. "Re-assessing Indonesia's role in the South China Sea", ISEAS Perspective, 2016(18): 1-13. 
Weatherbee, D. E., 2017. "Indonesia's foreign policy in 2016", Southeast Asian Affairs, 2017: 163-176.

\section{Online Article}

Augesti, A., 2018. "Paparkan konsep Indo-Pacific ke ASEAN, Menlu Retno Marsudi: Semua dukung sentralitas ASEAN (Explain the concept of Indo-Pacific to ASEAN, foreign Minister Retno Marsudi: All Supports ASEAN centrality)”. Liputan6. com, August 8. [online] in https://www.liputan6.com/global/read/3613657/ paparkan-konsep-indo-pasifik-ke-asean-menlu-retno-marsudi-semua-dukungsentralitas-asean [accessed on 4 May 2019].

Sumantri, B. S., 2014. "Bagi Jokowi bukan sekadar simbolisme (To Jokowi it is not just symbolism)". Kompas.com, October, 27. [Online] in https://nasional.kompas. com/read/2014/10/27/19311031/Bagi.Jokowi.Bukan.Sekadar.Simbolisme [accessed on 13 May 2019].

Chaudhury, D. R., 2018. "India to hold quad security dialogue with US, Australia and Japan this week". The Economic Times, November 12. [Online]. in https:// economictimes.indiatimes.com/news/defence/india-to-hold-quad-securitydialogue-with-us-japan-and-australia-this-week/articleshow/66583969. cms?from=mdr [accessed on 22 March 2019].

Jiangtae, S., and L. Zhou, 2017. "Wary China on 'quad' bloc after officials from US, Japan, India, and Australia meet on ASEAN sidelines". South China Morning Post, November 13. [Online] in https://www.scmp.com/news/china/diplomacydefence/article/2119719/wary-china-quad-bloc-watch-after-officials-us-japan [accessed on 2 May 2019].

Martinez, L., 2018. "US Pacific command renamed US Indo-Pacific command". $A B C$ News, May 30. [Online]. in https://abcnews.go.com/US/us-pacific-commandrenamed-us-indo-pacific-command/story?id=55539935 [accessed on 1 May 2019]

Natalegawa, M., 2013. "An Indonesian perspective on the Indo-Pacific". The Jakarta Post, May 20. [Online]. in https://www.thejakartapost.com/news/2013/05/20/ an-indonesian-perspective-indo-pacific.html [accessed on 2 March 2019].

Parameswaran, P., 2015. "Vietnam deeply concerned by Indonesia's war on illegal fishing", The Diplomat, August 21. [Online] in https://thediplomat. com/2015/o8/vietnam-deeply-concerned-by-indonesias-war-on-illegalfishing/ [accessed on 3 January 2019].

Trump, D. J., 2017. "Remarks by President Trump at the APEC CEO summit, Da Nang Vietnam". [online] in https://www.whitehouse.gov/briefings-statements/ remarks-president-trump-apec-ceo-summit-da-nang-vietnam/ [accessed on 21 April 2019]. 
Tham, J., 2018. What's in Indonesia's Indo-Pacific cooperation concept? The Diplomat, May 16. [Online] in https://thediplomat.com/2018/o5/whats-in-indonesiasindo-pacific-cooperation-concept/ [accessed on 11 May 2019].

Komisi Pemilihan Umum, 2014. "Visi misi Jokowi-Jusuf Kalla (Vision and mission of Jokowi-Jusuf Kalla)" [online] in https://www.kpu.go.id/koleksigambar/Visi_ Misi_JOKOWI-JK.pdf [accessed on 1 December 2004].

\section{Others}

Alatas, A. 1991. Sambutan Menteri Luar Negeri Republik Indonesia pada pembukaan lokakarya pengelolaan potensi-potensi konflik di Laut China Selatan, Bandung 15 Juli 1991 (Address of the foreign minister of the Republic of Indonesia on the workshop of managing potential conflict in the South China Sea, Bandung, July 15, 1991). Jakarta: Departemen Luar Negeri.

Indonesian Ocean Policy, 2017. Jakarta: Coordinating Ministry for Maritime Affairs Republic of Indonesia. 